Research Article

\title{
Hydration Properties of STS-Refining Slag-Blended Blast Furnace Slag Cement
}

\author{
Bong Suk Cho ${ }^{1}{ }^{1}$ and Young Cheol Choi ${ }^{2}{ }^{2}$ \\ ${ }^{1}$ Environment and Resources Research Group, Research Institute of Industrial Science and Technology, 67 Chengnam-ro, \\ Nam-gu, Pohang, Republic of Korea \\ ${ }^{2}$ Department of Civil and Environmental Engineering, Gachon University, 1342 Seongnamdaero, Sujeong-gu, Seongnam-si, \\ Gyeonggi-do 13120, Republic of Korea \\ Correspondence should be addressed to Young Cheol Choi; zerofe@gachon.ac.kr
}

Received 24 February 2018; Revised 22 April 2018; Accepted 30 April 2018; Published 17 May 2018

Academic Editor: Fernando Rubio-Marcos

Copyright ( $\odot 2018$ Bong Suk Cho and Young Cheol Choi. This is an open access article distributed under the Creative Commons Attribution License, which permits unrestricted use, distribution, and reproduction in any medium, provided the original work is properly cited.

\begin{abstract}
The refining process using an aluminum deoxidizer for fabricating stainless steel generated steel slag (STS-refining slag (SRS)) that contains a large amount of $\mathrm{Al}_{2} \mathrm{O}_{3}$ and is a compound of mainly $12 \mathrm{CaO} \cdot 7 \mathrm{~A}_{12} \mathrm{O}_{3}$ and $3 \mathrm{CaO} \cdot \mathrm{A}_{12} \mathrm{O}_{3}$. When SRS was mixed with slag cement, rapid exothermic reaction occurred in the initial phase of hydration. During the hydration of slag cement and SRS, a large quantity of $x \mathrm{CaO}-y \mathrm{Al}_{2} \mathrm{O}_{3}-z \mathrm{H}_{2} \mathrm{O}$ hydrate was observed. Until $10 \%$ weight replacement ratio of SRS to slag cement, the compressive strength was in the same level as in the existing slag cement. However, $20 \%$ replacement was accompanied by much strength degradation and high drying shrinkage. When a mixture of SRS and gypsum was added to slag cement, ettringite $\left(3 \mathrm{CaO} \cdot \mathrm{Al}_{2} \mathrm{O}_{3} \cdot 3 \mathrm{CaSO}_{4} \cdot 32 \mathrm{H}_{2} \mathrm{O}\right)$ was actively created in the initial hydration phase. The compressive strength of the OPC-BFS-SRSgypsum binder at 91 days was $91 \%$ of that of slag cement (B50) and was similar to that of OPC (O100). Besides, drying shrinkage was almost half that of slag cement, which indicates excellent performance for shrinkage. In case SRS is adequately used, which is an industrial by-product of the steel-making process, high shrinkage, a basic problem of slag cement, will be mitigated.
\end{abstract}

\section{Introduction}

The concrete shrinkage is a reduction of volume occurring when the relative humidity in capillary pores decreases during hydration. When a water/binder ratio is low and much blast furnace slag powder is used, the size of shrinkage increases and thus early-age cracking is more likely to happen $[1,2]$. The conventional preventive methods of shrinkage cracks of concrete include expanding cement [3], surface treatments like prestressed technology [4], shrinkage-reducing admixtures [5-9], optimal temperature and humidity curing conditions [10], and expansive additives [11, 12].

Among these methods for controlling concrete shrinkage, the expansive additives can increase the volume of cement paste in concrete by utilizing specific chemical reactions. In other words, ettringite $\left(3 \mathrm{CaO} \cdot \mathrm{Al}_{2} \mathrm{O}_{3} \cdot 3 \mathrm{CaSO}_{4} \cdot 32 \mathrm{H}_{2} \mathrm{O}\right)$ is created at an early age, and the growth of ettringite expands cement paste and compensates for shrinkage. $\mathrm{CaO}+\mathrm{CaSO}_{4}$ based and calcium sulfoaluminate- (CSA-) based expansive additives are representative ones [13-17]. These additives can prevent early-age cracking of concrete by inducing an appropriate expansion. However, since the expansive additives are much more expansive than the ordinary Portland cement, they cannot be widely applied to construction sites. Recent researches focus on enhancing the price competitiveness of inorganic expansive additives and utilizing industrial byproducts for expansive additives [6].

As various types of steel products are demanded and supplied, various types of slag are produced in each process. Especially, when stainless steel, which is a high-value product, is fabricated, even a very small amount of oxygen mixed with steel needs to be removed. Aluminum, $\mathrm{Fe}-\mathrm{Si}$, and $\mathrm{Fe}-\mathrm{Mn}$, which have a high affinity with oxygen, are used as deoxidizers. The steel by-product of this process is refining slag (STS-refining slag (SRS)). SRS generated from POSCO in 


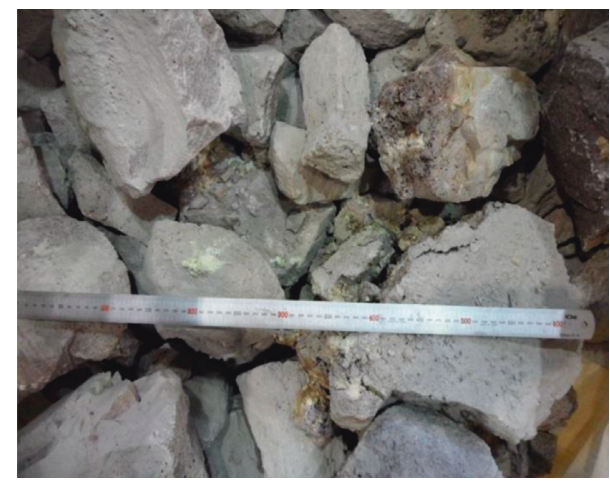

FIgURE 1: Raw material of STS-refining slag.

Korea is a by-product of the STS-refining process using aluminum as a main deoxidizer (Figure 1).

The SRS produced in Korea is finally transformed into a $\mathrm{CaO}-\mathrm{Al}_{2} \mathrm{O}_{3}$ compound after the hot melt reaction of $\mathrm{CaO}$ (resulting from limestone, which is a supplementary material) included in the slag layer and aluminum inserted as a main reducing agent. As shown in Figure 1, SRS is produced in lumps. The annual SRS is around 140,000 tons. Among them, the amount of the flux material (less than $10 \mathrm{~mm}$ ) used in the steel-manufacturing process is 50,000 tons. The remaining 90,000 tons are crushed to a size of $25 \mathrm{~mm}$ or $40 \mathrm{~mm}$ and simply used as landfill materials. POSCO in Korea wants to derive new high-value-added applications of SRS.

Since SRS contains a large amount of $3 \mathrm{CaO} \cdot \mathrm{Al}_{2} \mathrm{O}_{3}$ among main composition minerals of the ordinary Portland cement (OPC) like $3 \mathrm{CaO} \cdot \mathrm{SiO}_{2}, 2 \mathrm{CaO} \cdot \mathrm{SiO}_{2}, 3 \mathrm{CaO} \cdot \mathrm{Al}_{2} \mathrm{O}_{3}$, and $4 \mathrm{CaO} \cdot \mathrm{Al}_{2} \mathrm{O}_{3} \cdot \mathrm{Fe}_{2} \mathrm{O}_{3}$, it can be effectively used as a cement additive. Moreover, as SRS also contains $12 \mathrm{CaO} \cdot 7 \mathrm{Al}_{2} \mathrm{O}_{3}$ along with $3 \mathrm{CaO} \cdot \mathrm{Al}_{2} \mathrm{O}_{3}$, if it is mixed with gypsum $\left(\mathrm{CaSO}_{4}\right)$, ettringite can be generated in the initial phase of hydration. This phenomenon may induce an expansion in such an initial phase, which can reduce shrinkage. Slag cement is generally composed of OPC and ground-granulated blast furnace slag (BFS). Since slag cement undergoes a large shrinkage in the initial phase of hydration, it may very likely cause shrinkage cracks of concrete [18-21]. Especially, in the case of slag cement with large BFS content, a large shrinkage may occur. Thus, when slag cement is applied to construction sites, an economic measure is necessary.

The aim of this research was to set up a method for reducing shrinkage of slag cement by using SRS and to find an effective method for recycling SRS, which is an industrial by-product. For this aim, physical and chemical properties of SRS were examined, and hydrate and physical properties of slag cement composites with only SRS or a mixture of SRS and gypsum were evaluated. Heat evolution analysis, XRD analysis and TG-DTA were conducted for various SRSrelated parameters, and compressive strength and drying shrinkage were also evaluated according to age.

\section{Experimental Details}

2.1. Materials. Table 1 presents physical properties and chemical composition of raw materials used in this research.
OPC with $3.13 \mathrm{~g} / \mathrm{cm}^{3}$ density and $3,415 \mathrm{~cm}^{2} / \mathrm{g}$ Blaine was used as cement. BFS was produced by POSCO, and its density and Blaine were $2.99 \mathrm{~g} / \mathrm{cm}^{3}$ and $4,340 \mathrm{~cm}^{2} / \mathrm{g}$, respectively. SRS is produced as a by-product in the refining process of stainless steel. Since the STS-refining process used aluminum as a deoxidizer to remove oxygen frommolten steel, SRS had a high content of $\mathrm{Al}_{2} \mathrm{O}_{3}$ (oxygen affinity: $\mathrm{K}>\mathrm{Ca}>\mathrm{Mg}>\mathrm{Al}>\mathrm{Ti}>\mathrm{C}>\mathrm{Si}>\mathrm{Mn}>\mathrm{Cr}>\mathrm{Fe}>$ $\mathrm{Ni}>\mathrm{Cu}$ ). The density and Blaine of SRS were $3.04 \mathrm{~g} / \mathrm{cm}^{3}$ and $4,010 \mathrm{~cm}^{2} / \mathrm{g}$, respectively.

Figure 2 shows XRD patterns of the test materials. In the STS-refining process, calcium oxide included in a slag layer and aluminum, which is used as a deoxidizer, made a high-temperature melt reaction to create a $\mathrm{CaO}-\mathrm{Al}_{2} \mathrm{O}_{3}$ compound, of which the main crystal phase consists of $12 \mathrm{CaO} \cdot 7 \mathrm{Al}_{2} \mathrm{O}_{3}$ and $3 \mathrm{CaO} \cdot \mathrm{Al}_{2} \mathrm{O}_{3} \cdot 12 \mathrm{CaO} \cdot 7 \mathrm{Al}_{2} \mathrm{O}_{3}$ and $3 \mathrm{CaO} \cdot \mathrm{Al}_{2} \mathrm{O}_{3}$ produced a rapid exothermic reaction against water to form $x \mathrm{CaO}-y \mathrm{Al}_{2} \mathrm{O}_{3}-z \mathrm{H}_{2} \mathrm{O}$ [22-26]. The pulverized particles of SRS had a plate shape, and the surface looked solid. The primary crystal phase of OPC was found to be $3 \mathrm{CaO} \cdot \mathrm{SiO}_{2}$ (alite) and $2 \mathrm{CaO} \cdot \mathrm{SiO}_{2}$ (belite). There were also small amounts of $3 \mathrm{CaO} \cdot \mathrm{Al}_{2} \mathrm{O}_{3}$ (calcium aluminate) and $4 \mathrm{CaO} \cdot \mathrm{Al}_{2} \mathrm{O}_{3} \cdot \mathrm{Fe}_{2} \mathrm{O}_{3}$ (calcium aluminate ferrite).

Calcium sulfate $\left(\mathrm{CaSO}_{4}\right)$ was found to be the main crystal phase in the gypsum, based on which it was classified as anhydrous gypsum. BFS showed the typical noncrystalline XRD pattern due to wet quenching.

The SRS powder is a nonmagnetic slag collected through the processes of drying, crushing, and magnetic separation. The powdered SRS particles are similar to a rough plate type with a surface that appears to be hard as shown in Figure 3. In particular, the surface of the BFS was very slick due to the glassy state on the grain surface formed through the shock chilling process.

2.2. Mixture Proportions and Test Methods. The blast furnace slag cement conventionally used in Korea is generally composed of OPC and BFS in a ratio of $5: 5$ to $6: 4$ [27]. In this research, the slag cement with the mixture of $50 \%$ OPC and $50 \%$ BFS was set to O100, and a part of BFS was replaced by only SRS or the mixture of SRS and gypsum. The slag cement composites consisting of OPC (O), BFS (B), SRS (S), and gypsum $(\mathrm{G})$ are called as O-B-S-G binders. As shown in Table 2, The O-B-S-G binders were mixed in the ratios of 100:0:0:0 (O100), 50:50:0:0 (B50), 50:40:10:0 (B40S10), $50: 40: 5: 5$ (B40-S5-G5), $50: 40: 0: 10$ (B40-G10), $50: 30: 20: 0$ (B30-S20), 50:30:15:5 (B30-S15-G5), 50:30:10: 10 (B30-S10-G10), $50: 30: 5: 15$ (B30-S5-G15), and 50:30:0:20 (B30-G20).

To evaluate heat evolution, XRD, and TG and drying shrinkage, slag-cement paste specimens were fabricated with the water/binder ratio of 0.4. Mortar specimens for compressive strength testing were manufactured using the ISO standard sand (ISO 679).

The hydration heat was measured at 30-second intervals using the calorimeter (MMC-511SV6; Rico Corp., Tokyo) for 7 days. The TG (EXSTAR 6000; Seiko Instrument Corp.) analysis of the paste specimen was implemented at the age of 
TABLE 1: Chemical composition and physical properties of the materials.

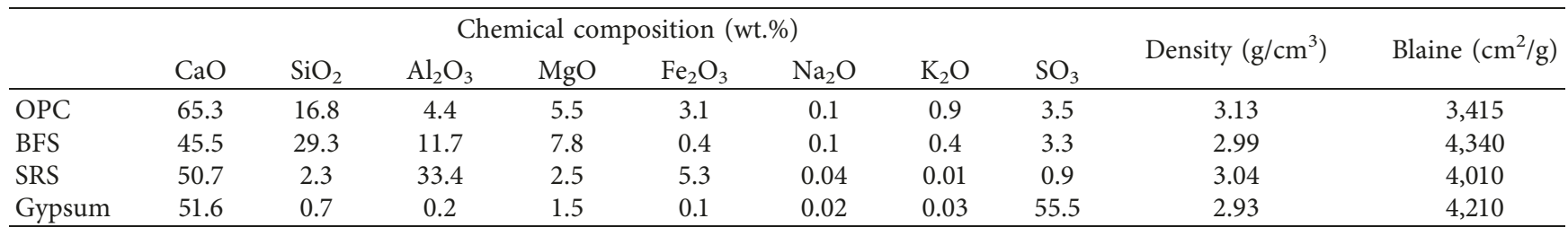

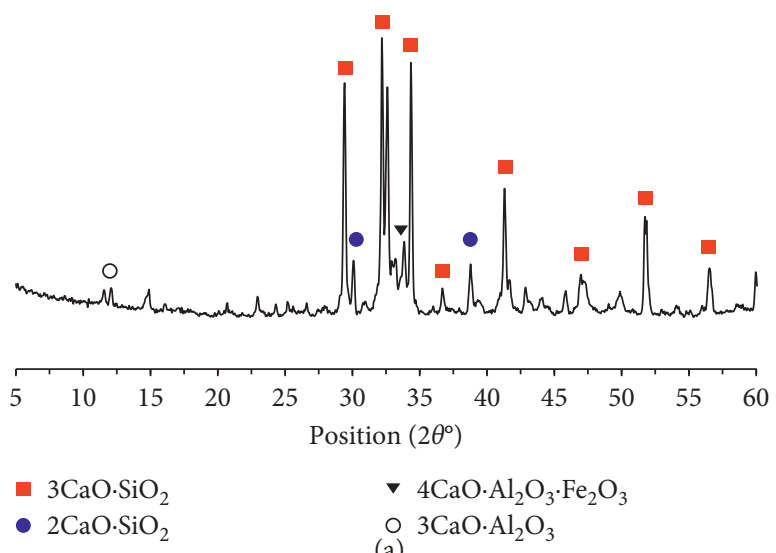

(a)

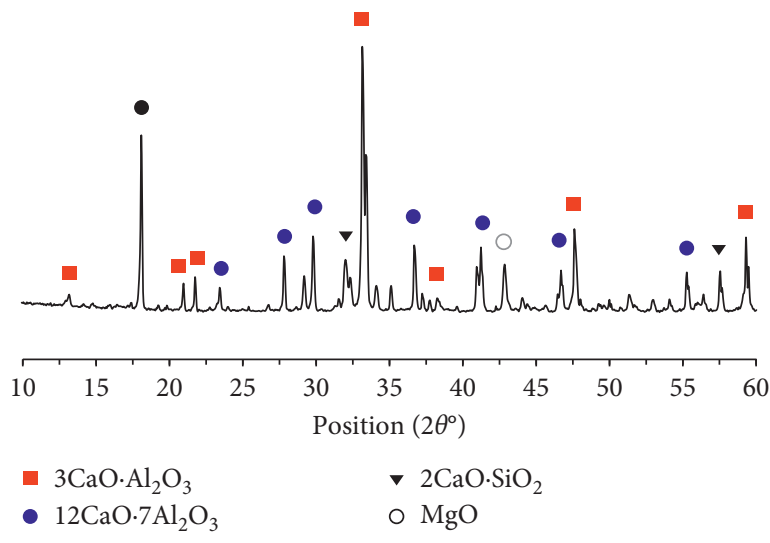

(c)

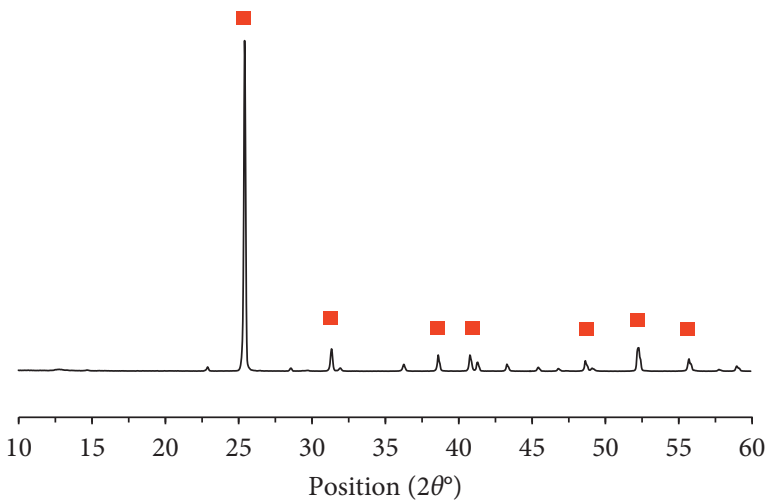

- $\mathrm{CaSO}_{4}$ (anhydrous gypsum)

(b)

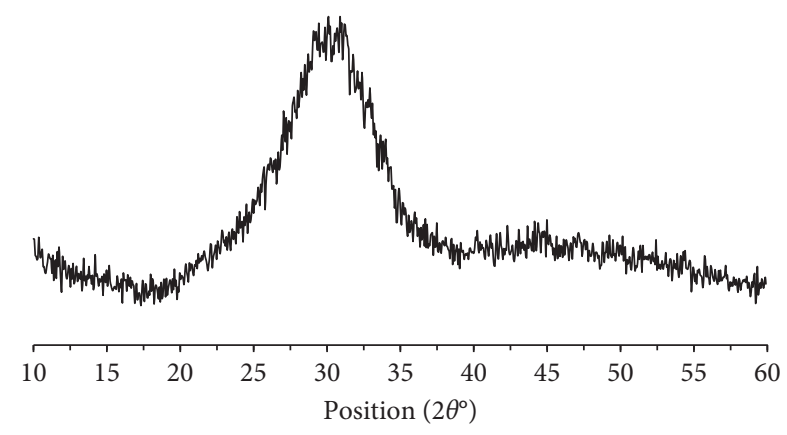

(d)

Figure 2: XRD spectra of the test materials. (a) OPC. (b) Gypsum. (c) SRS. (d) BFS.

3 days and 91 days. The temperature in the instrument was raised from $20^{\circ} \mathrm{C}$ up to $1100^{\circ} \mathrm{C}$ under the atmospheric condition. The XRD (D/Max-2500V; Rigaku Corp.) and SEM (S-4300SE; Hitachi Corp.) analyses for paste specimens were performed in order to investigate hydration products.

The compressive strength of mortar was measured in compliance with ISO 679. A mortar specimen of dimensions $40 \times 40 \times 160 \mathrm{~mm}$ was made using a jolting machine and water-cured at $20 \pm 2^{\circ} \mathrm{C}$. The compressive strength of the specimen was then measured at $3,7,28,56$, and 91 days. In addition, the paste specimen $(25.4 \times 25.4 \times 254 \mathrm{~mm})$ for the drying shrinkage test was cured at $20 \pm 3^{\circ} \mathrm{C}$ under the air condition for 1 day, after being detached from the mold. Then, the changes in length were measured under conditions of $20 \pm 3^{\circ} \mathrm{C}$ and $60 \%$ humidity for 180 days [28].

\section{Results and Discussion}

3.1. Hydration Heat Evolution. Figure 4 shows the results of an evaluation of hydration heat of O100, B50, B30-S20, B30S10-G10, and B30-G20. The hydration graph over time in Figure 4 was to analyze the hydration phase by phase.

The graph depicts heat evolution rates and cumulative heat flows simultaneously. The first peak occurred within 30 minutes immediately after being mixed with water. The largest value of the first peak occurred in B30-S20 and O100 (about $1.40 \mathrm{~J} / \mathrm{hg}$ ), followed by B30-S10-G10 (1.27 J/hg), 50B30S0G20 (0.57 J/hg), and B50 (0.20 J/hg). Especially, the exothermic peak of B30S20 was about 7 times that of B50 and was also strong enough to maintain for about one hour. The reason why B30-S20 and B30-S10-G10 had a strong 


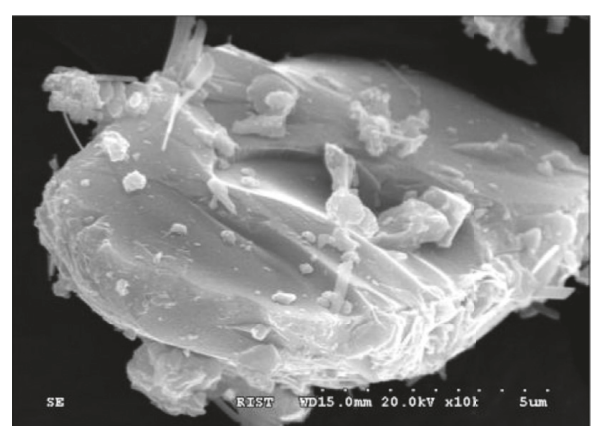

(a)

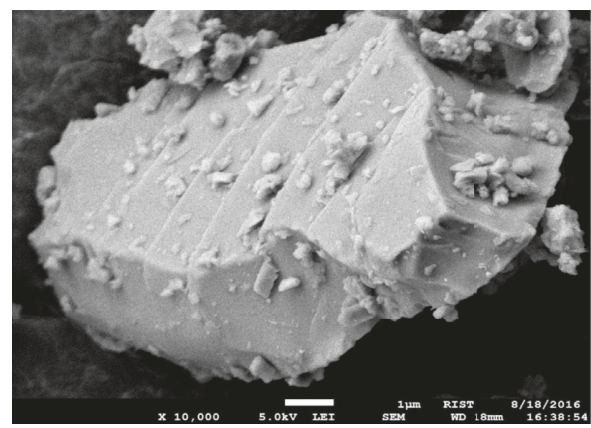

(c)

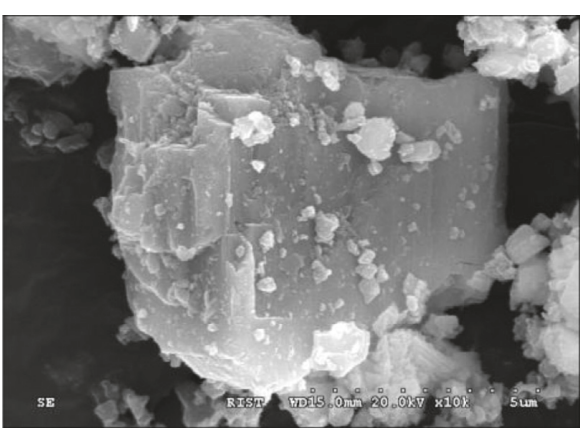

(b)

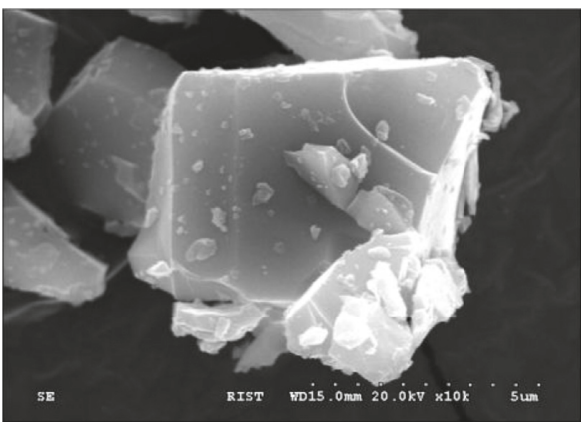

(d)

Figure 3: SEM image of the particle. (a) OPC. (b) Gypsum. (c) SRS. (d) BFS.

TABLE 2: Mixture proportions of binders (unit \%).

\begin{tabular}{|c|c|c|c|c|c|}
\hline & Mix. ID & $\mathrm{OPC}(\mathrm{O})$ & BFS (B) & SRS (S) & Gypsum (G) \\
\hline $\mathrm{OPC}$ & $\mathrm{O} 100$ & 100 & - & - & - \\
\hline Blast furnace slag cement & B50 & 50 & 50 & - & - \\
\hline \multirow{8}{*}{ O-B-S-G binders } & B40-S10 & 50 & 40 & 10 & - \\
\hline & B40-S5-G5 & 50 & 40 & 5 & 5 \\
\hline & B40-G10 & 50 & 40 & - & 10 \\
\hline & B30-S20 & 50 & 30 & 20 & \\
\hline & B30-S15-G5 & 50 & 30 & 15 & 5 \\
\hline & B30-S10-G10 & 50 & 30 & 10 & 10 \\
\hline & B30-S5-G15 & 50 & 30 & 5 & 15 \\
\hline & B30-G20 & 50 & 30 & - & 20 \\
\hline
\end{tabular}

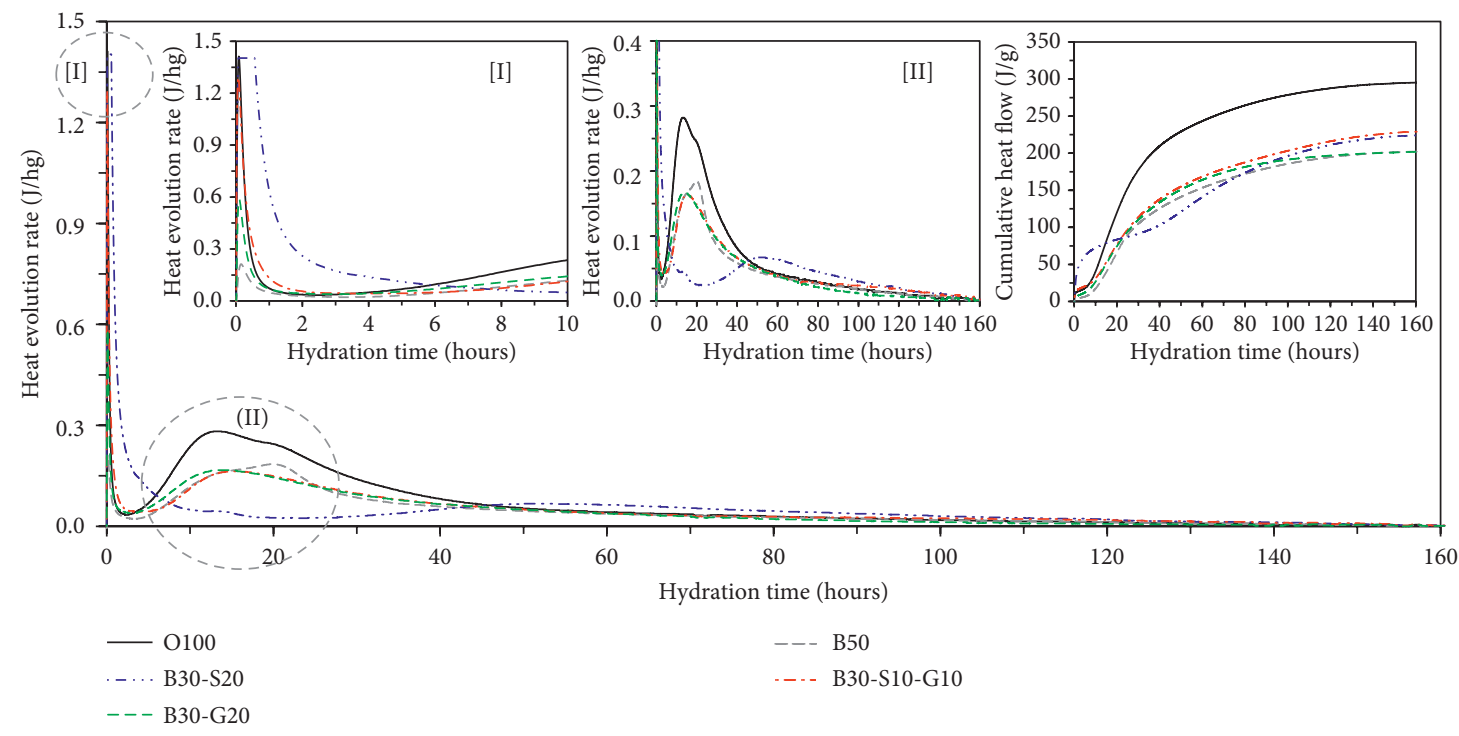

Figure 4: Hydration heat evolution with binder types. 


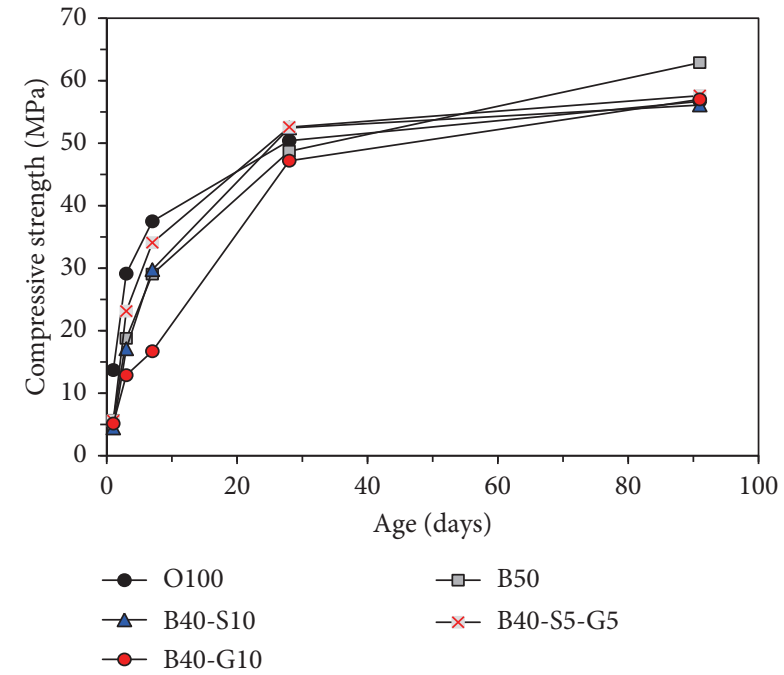

(a)

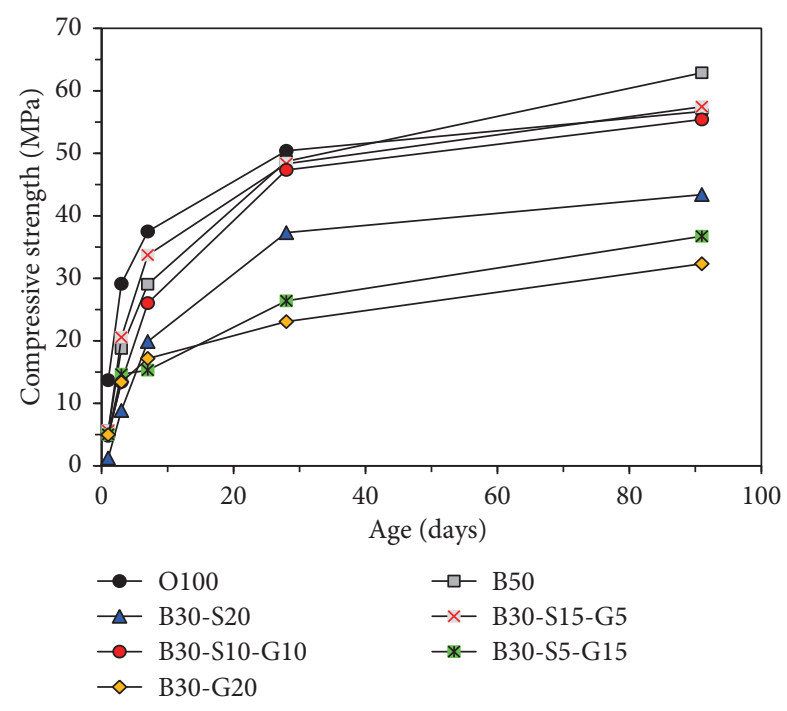

(b)

Figure 5: Development of compressive strength with binder types. (a) $\mathrm{O} 50 \mathrm{~B} 40+\mathrm{S} \& \mathrm{G}$ series. (b) O50B30 + S\&G series.

exothermic reaction was that large quantities of $3 \mathrm{CaO} \cdot \mathrm{Al}_{2} \mathrm{O}_{3}$ and $12 \mathrm{CaO} \cdot 7 \mathrm{Al}_{2} \mathrm{O}_{3}$, which were contained in SRS, caused a rapid exothermic reaction to water $[19,29] .3 \mathrm{CaO} \cdot \mathrm{Al}_{2} \mathrm{O}_{3}$ and $12 \mathrm{CaO} \cdot 7 \mathrm{Al}_{2} \mathrm{O}_{3}$ in SRS create $x \mathrm{CaO}-y \mathrm{Al}_{2} \mathrm{O}_{3}-z \mathrm{H}_{2} \mathrm{O}$ hydrate through the reaction with water.

In addition, when a mixture of SRS $\left(3 \mathrm{CaO} \cdot \mathrm{Al}_{2} \mathrm{O}_{3}\right.$ and $\left.12 \mathrm{CaO} \cdot 7 \mathrm{Al}_{2} \mathrm{O}_{3}\right)$ and gypsum $\left(\mathrm{CaSO}_{4}\right)$ reacts with water, ettringite $\left(3 \mathrm{CaO} \cdot \mathrm{Al}_{2} \mathrm{O}_{3} \cdot 3 \mathrm{CaSO}_{4} \cdot 32 \mathrm{H}_{2} \mathrm{O}\right)$ is generated. However, as opposed to the initial rapid exothermic reaction, $\mathrm{B} 30$ S20 showed the lowest exothermic value among the binders after about 6 hours. The second peaks occurred between 12 and $20 \mathrm{hr}$, and $\mathrm{O} 100$ showed the largest value of $0.28 \mathrm{~J} / \mathrm{hg}$ around $12.8 \mathrm{hr}$, which was followed by $\mathrm{B} 50(0.18 \mathrm{~J} / \mathrm{hg}$ at $19.6 \mathrm{hr}), \quad \mathrm{B} 30-\mathrm{G} 20(0.17 \mathrm{~J} / \mathrm{hg}$ at $13.0 \mathrm{hr}), \mathrm{B} 30-\mathrm{S} 10-\mathrm{G} 10$ $(0.16 \mathrm{~J} / \mathrm{hg}$ at $14.8 \mathrm{hr})$, and $\mathrm{B} 30-\mathrm{S} 20(0.07 \mathrm{~J} / \mathrm{hg}$ at $49.9 \mathrm{hr})$. It was remarkable that $\mathrm{B} 30-\mathrm{S} 20$ had the strongest initial exothermic reaction after being mixed with water, but its

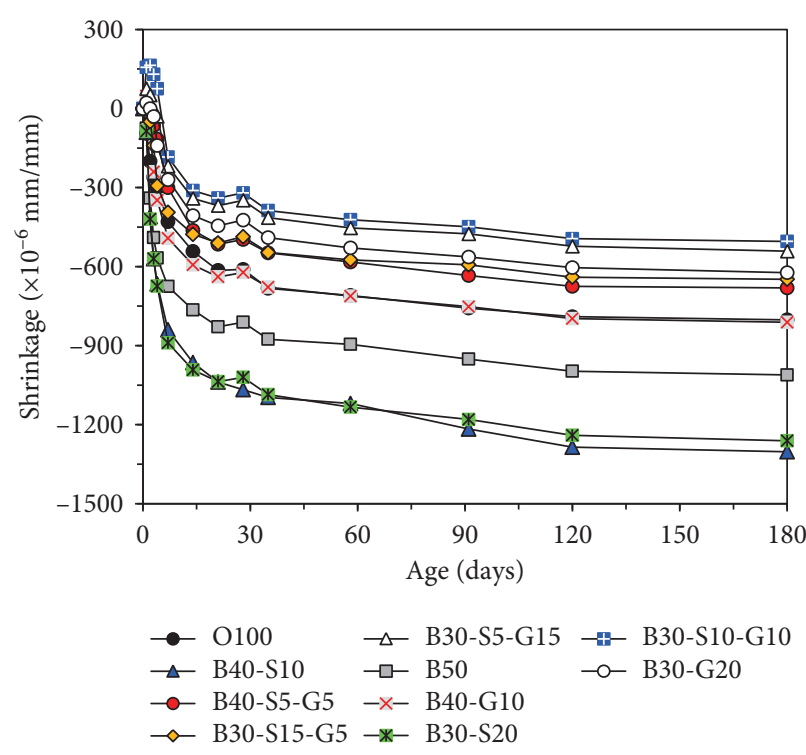

(a)

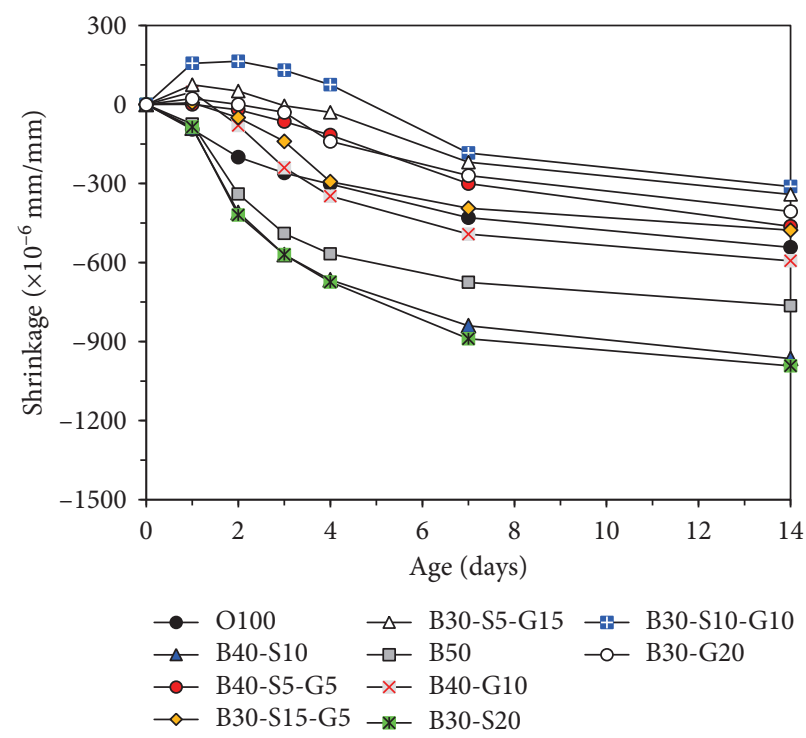

(b)

FIGURE 6: Drying shrinkage of paste specimens with binder types for (a) 180 days and (b) 14 days.

second peak was very low and also occurred late. The largest cumulative heat for $160 \mathrm{hr}$ was $295 \mathrm{~J} / \mathrm{g}$, which occurred in $\mathrm{O} 100$. When the cumulative heat of O100 was taken as $100 \%$, B50, B30-S20, O50G30S10G10, and B30-G20 had the relative percentages of $68 \%, 76 \%, 78 \%$, and $68 \%$, respectively.

3.2. Compressive Strength. Figure 5 illustrates the compressive strength of the mortar with binder types. Until 7 days, O100 showed incomparably high compressive strength among all the specimens. However, after 28 days, the difference in compressive strength between $\mathrm{O} 100$ and the remaining specimens decreased gradually. The compressive strength of B50 was lower than that of OPC until 7 days and became similar to that of $\mathrm{O} 100$ at 28 days and finally had the 


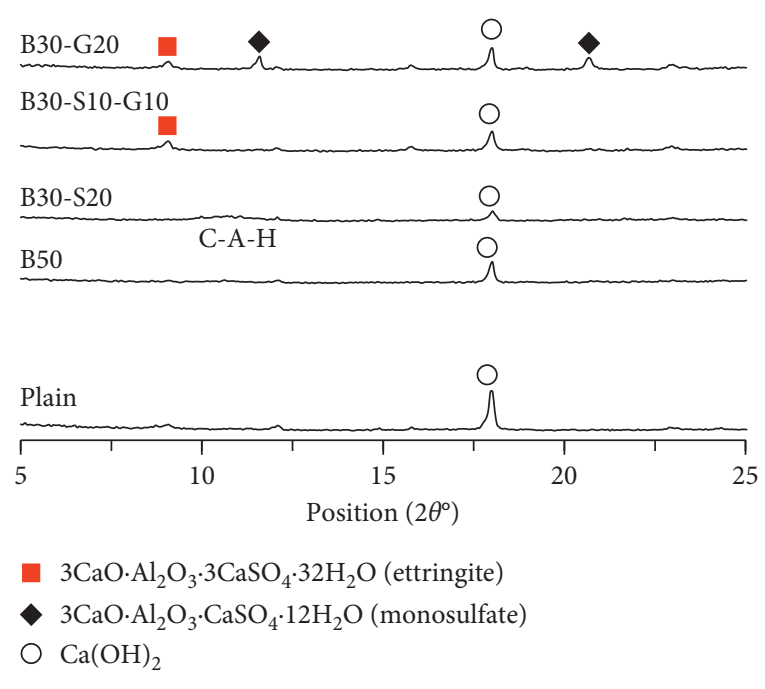

(a)

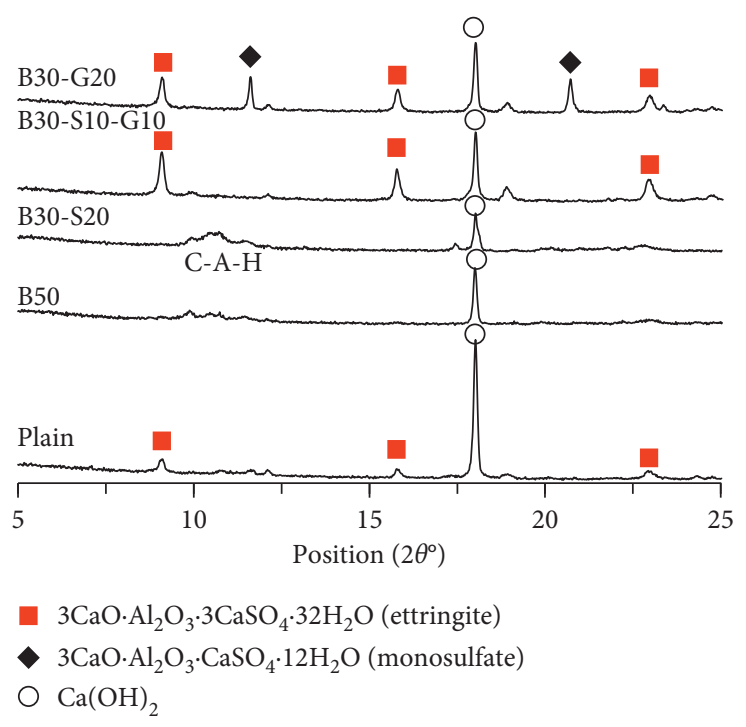

(b)

FIgURE 7: XRD spectra of hydrates at (a) 3 days and (b) 91 days.

highest value among all the specimens including O100. This is because the latent hydraulic properties of BFS made a long-term strength improvement. As compared to B40G10, B40-S10, B30-S20, and B30-G20, to which either gypsum or SRS alone was added, B40-S5-G5, B30-S15-G5, and B30-S10-G10, to which the mixture of SRS and gypsum was applied, showed higher values of compressive strength.

Among O-B-S-G binders, B40-S5-G5 and B30-S15-G5 showed the highest overall compressive strength and had a similar value at each age. In particular, their compressive strength was similar to that of B50 at 1 day but became higher at 7 days. Then, they had a similar value to B50 again at 28 days. At 91 days, the compressive strength of B40-S5G5 and B30-S15-G5 was about 10\% lower than that of B50 but was similar to that of O100. B50 had the compressive strength of $62.9 \mathrm{MPa}$ at 91 days, which was the highest value among all the binders. B40-S5-G5, B30-S15-G5, and O50B40G had similar values of $57.6 \mathrm{MPa}, 57.5 \mathrm{MPa}$, and 57.0 MPa, respectively, taking the second place. Next, O100 $(56.7 \mathrm{MPa})$ and B40-S10 (56.1 MPa) showed similar values, followed by B30-S10-G10 (55.4 MPa), B30-S20 (43.4 MPa), O50B30S5G15 (36.7 MPa), and B30-G20 (32.3 MPa). Among the binders to which SRS and gypsum were mixed, B30-S15-G5 and B30-S10-G10 had relatively higher values than O50B30S5G15. To be specific, under the condition that the content of SRS-gypsum mixture does not exceed $20 \%$, when the content of gypsum exceeded $10 \%$, the consequential compressive strength decreased. Consequently, as the compressive strength of ettringite is much affected by SRS and gypsum, it is necessary to optimize their mixing ratio and content and to maintain the quality.

3.3. Drying Shrinkage. Figure 6(a) shows the evaluation results of the drying shrinkage of the paste with O-B-R-G binders up to 180 days. Figure 6(b) shows the initial trend by illustrating the drying shrinkage until 14 days. The overall trend of drying shrinkage is clearly displayed according to the binder type. The early-age characteristics of shrinkage and expansion ultimately affect the shrinkage compensating at a later age. In other words, an appropriate compensation for expansion at an early age is essential to reduce shrinkage. As for the shrinkage characteristics of binders at 180 days, among the binders that did not contain gypsum, B40-S10 and B30-S20 had the shrinkage of $-1,300 \times 10^{-6}$ and $-1,270 \times 10^{-6}$, respectively, which were about 1.3 times the shrinkage of B50 $\left(-1,010 \times 10^{-6}\right)$. However, B40-G10 that did not contain SRS decreased its shrinkage below that of B50 and had a similar result to O100 $\left(-800 \times 10^{-6}\right)$. B30-G20 that contained more gypsum than B40-G10 had a still lower shrinkage of $-620 \times 10^{-6}$. Other specimens (B40-S5-G5, B30-S15-G5, O50B30S5G15, and B30-S10-G10), in which both SRS and gypsum were used, showed the drying shrinkage range of $-690 \times 10^{-6}$ to $-500 \times 10^{-6}$, indicating a significant decrease in shrinkage as compared to B50.

The early ages (1 to 4 days) revealed a remarkable expansion tendency in B30S10G10 and B30S5G15. Especially, B30S10G10 expanded more significantly than B30S5G15. In other words, when the mixture of SRS and gypsum was hydrated, ettringite was generated and developed (development of crystals) in capillary pores and thus a swelling pressure occurred, which resulted in expansion at the early ages.

In particular, the shrinkage of B30-S10-G10 was so low as to be only $62 \%$ and $50 \%$ of $\mathrm{O} 100$ and B50, respectively. The shrinkage of O50B30S5G15 at 180 days was $80 \%$ and $64 \%$ of $\mathrm{O} 100$ and B50, respectively, also indicating a good effect of reducing shrinkage. Accordingly, the appropriate application of SRS and gypsum could decrease the shrinkage of the existing slag cement by over $50 \%$. On the contrary, O50B30RS20 and B40-S10, which used only SRS as an admixture, showed the highest shrinkage level. Although SRS is an industrial by-product of the steel-making process, 
it contains useful components like $3 \mathrm{CaO} \cdot \mathrm{Al}_{2} \mathrm{O}_{3}$ and $12 \mathrm{CaO} \cdot 7 \mathrm{Al}_{2} \mathrm{O}_{3}$. For this reason, SRS can be effectively used as a cement material. However, if SRS alone is used, an excessive shrinkage can occur, which will result in damages including cracks. Thus, a rigorous quality management is required for utilizing SRS.

As the reduction of the construction period is still the first priority in many construction sites in Korea, a Blaine value tends to be raised in order to develop the initial strength of slag cement. This frequently results in a large drying shrinkage, and such an adverse effect causes shrinkage cracks and increases the maintenance cost significantly. Consequently, the appropriate use of SRS and gypsum will solve the problem of large shrinkage, which is a disadvantage of slag cement.

3.4. XRD, TG, and SEM Analyses of Hydrates. The XRD spectra at 3 days and 91 days are illustrated in Figure 7. As shown in Figure 7, the hydrates had higher and clearer peaks at 91 days than at 3 days. B30-S10-G10 and B30-G20, to which gypsum was added, showed that B30-S10-G10 had slightly higher ettringite peaks than B30-G20. Overall, the ettringite peaks of B30-S10-G10 were observed to be the most intensive among all the specimens. In the case of B30G20, where gypsum was put excessively, a peak of monosulfate was found. In B30-S20, which contained the largest amount of SRS, calcium aluminate hydrates $\left(x \mathrm{CaO}-y \mathrm{Al}_{2} \mathrm{O}_{3}\right.$ $\left.z \mathrm{H}_{2} \mathrm{O}\right)$ and $3 \mathrm{CaO} \cdot \mathrm{Al}_{2} \mathrm{O}_{3}$ formed the main peaks. $\mathrm{O} 100$ and B50 showed an almost similar hydrate pattern, and their main hydrates were $\mathrm{Ca}(\mathrm{OH})_{2}$ and ettringite. In $\mathrm{B} 50$, the $\mathrm{Ca}(\mathrm{OH})_{2}$ peak appearing around $18^{\circ}$ was lower than that of OPC. This may be because the amount of $\mathrm{Ca}(\mathrm{OH})_{2}$ generated from OPC was decreasing in the latent reaction with BFS.

Figure 8 shows the results of thermal analysis for pastes of O100, B50, B30-S20, B30-S10-G10, and B30-G20 at the age of 3 days and 91 days. The overall trend was that the specimens showed a steeper gradient of the weight loss curve at 91 days than at 3 days. This is because the specimens generated more hydrates at 91 days, and dehydration of water molecules occurred remarkably under high-temperature condition [30-33].

The weight loss phenomenon around $100^{\circ} \mathrm{C}$ indicates dehydration (evaporation of crystallization water) of ettringite hydrates [34-36]. In around $100^{\circ} \mathrm{C}, \mathrm{B} 30-\mathrm{G} 20$ and B30-S10-G10 showed a relatively larger weight loss than $\mathrm{O} 100$ and B50. This is because B30-G20 and B30-S10-G10 contained a lot of ettringite hydrates. Especially, B30-S10G10 had the largest weight loss and was followed by B30-G20 and B30-S20. The weight loss phenomenon around $250 \sim 350^{\circ} \mathrm{C}$ means dehydration of $x \mathrm{CaO}-y \mathrm{Al}_{2} \mathrm{O}_{3}-z \mathrm{H}_{2} \mathrm{O}$ hydrate. B30-S20 containing a large amount of $x \mathrm{CaO}-y \mathrm{Al}_{2} \mathrm{O}_{3}-z \mathrm{H}_{2} \mathrm{O}$ showed the largest weight loss at 91 days.

The weight loss curves around $400 \sim 500^{\circ} \mathrm{C}$ indicate the dehydration of $\mathrm{H}_{2} \mathrm{O}$ molecules due to the pyrolysis of $\mathrm{Ca}(\mathrm{OH})_{2}$. O100 showed a larger weight loss than other specimens, which indicates that $\mathrm{O} 100$ generated the largest amount of $\mathrm{Ca}(\mathrm{OH})_{2}$ hydrate.

The weight loss curves around $700^{\circ} \mathrm{C}$ indicate the decarbonation of the calcium carbonate in the hydrated

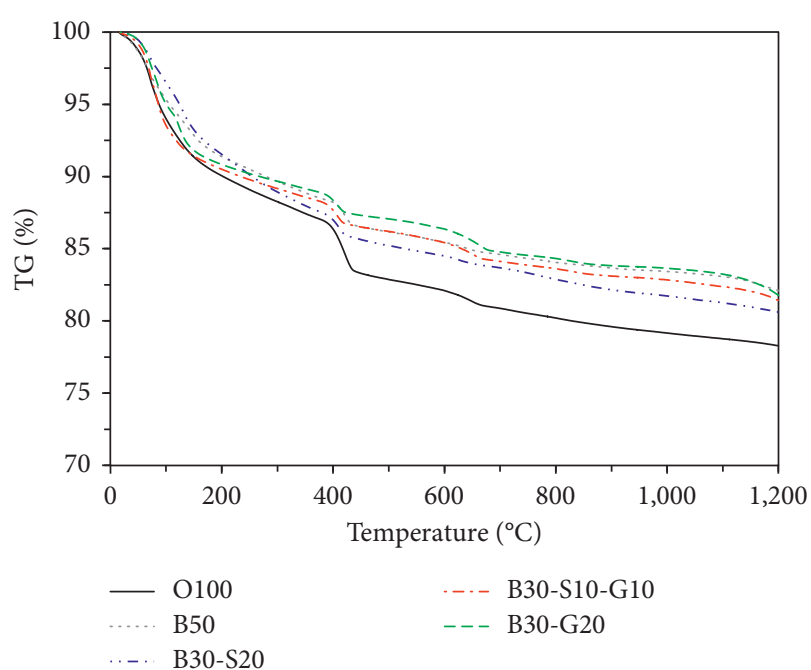

(a)

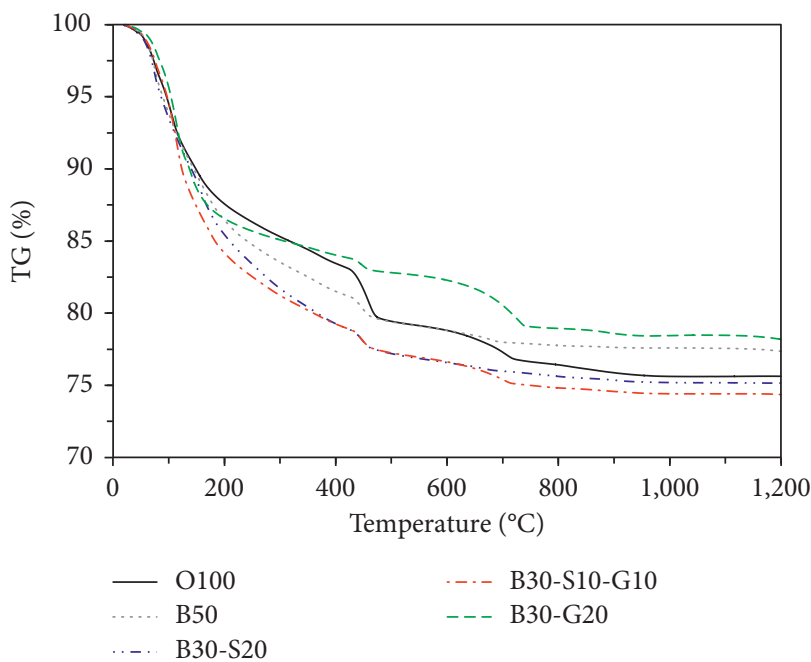

(b)

FIgURE 8: Thermogravimetric analysis with binder types at (a) 3 days and (b) 91 days.

compound $[37,38]$. There was no significant difference at 3 days, but the weight loss curve of B30-G20 was remarkably steeper than that of the other specimens at 91 days. The final weight loss of the specimens at $1000^{\circ} \mathrm{C}$ was $81 \sim 87 \%$ at 3 days and $74 \sim 78 \%$ at 91 days.

Figure 9 presents SEM images of hydrates of O100, B30S20, B30-S10-G10, and B30-G20 at 91 days. B30-S20 shows mainly $x \mathrm{CaO}-y \mathrm{Al}_{2} \mathrm{O}_{3}-z \mathrm{H}_{2} \mathrm{O}$ and $x \mathrm{CaO}-y \mathrm{SiO}_{2}-z \mathrm{H}_{2} \mathrm{O}$ hydrates, while the main hydrate of B30-S10-G10 and B30-G20 is ettringite. Besides, B30-S10-G10 has larger and thicker ettringite hydrates than $\mathrm{B} 30-\mathrm{G} 20$. As mentioned above, this demonstrates that the coexistence of SRS $\left(\mathrm{CaO}-\mathrm{Al}_{2} \mathrm{O}_{3}\right.$ compound) and $\mathrm{CaSO}_{4}$ is more effective in generating ettringite hydrates.

\section{Conclusions}

It was found that a more economical and eco-friendly shrinkage-reduced slag cement can be manufactured using 


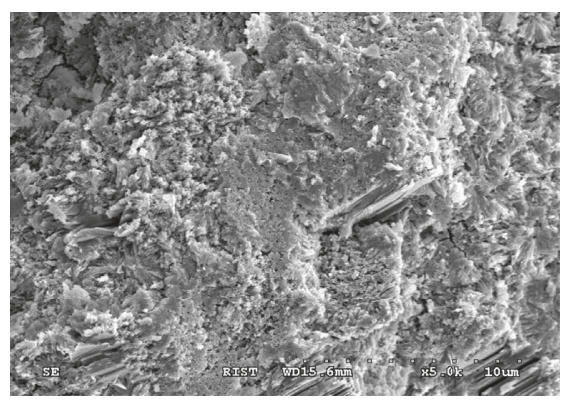

(a)

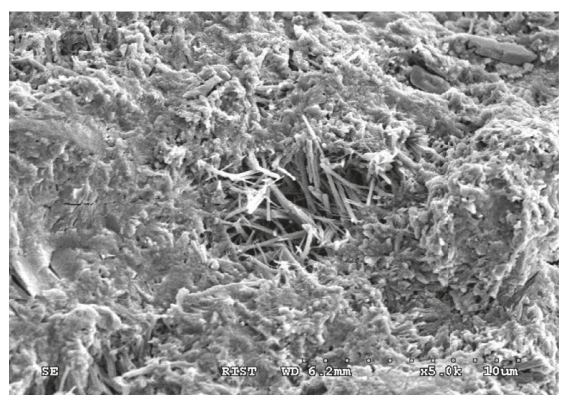

(d)

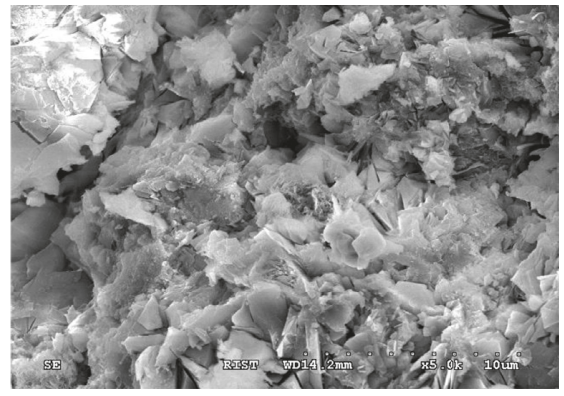

(b)

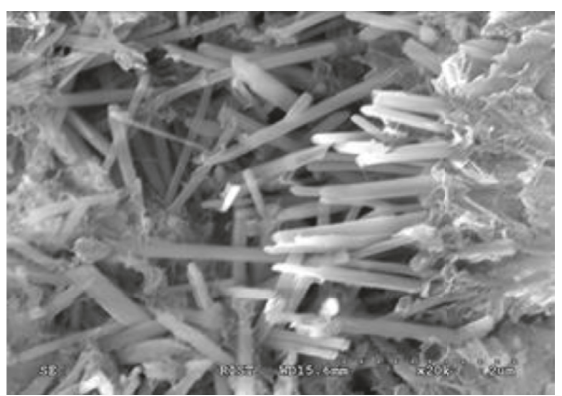

(e)

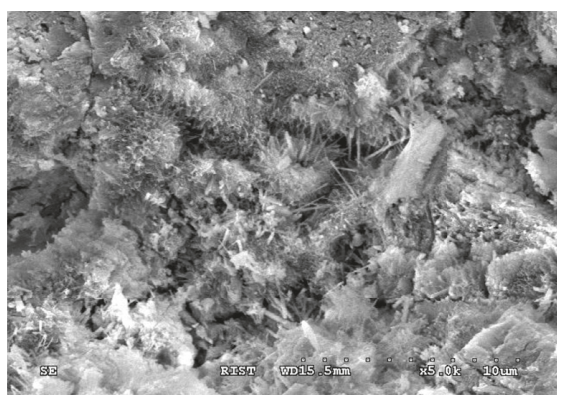

(c)

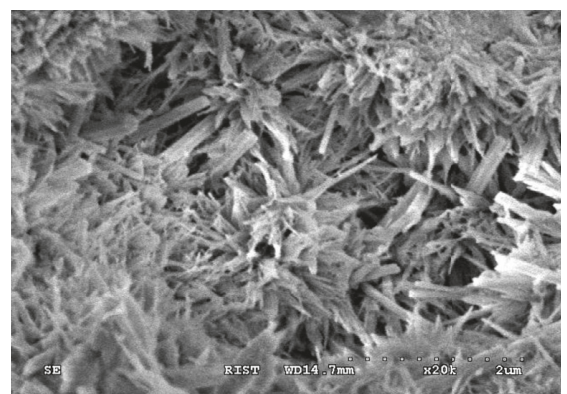

(f)

Figure 9: SEM images of hydrates. (a) O100 (×5k). (b) B30-S20 (×5k). (c) B30-S10-G10 (×5k). (d) B30-G20 (×5k). (e) B30-S10-G10 (×20k). (f) B30-G20 (×20k).

SRS, which is a by-product of the steel-making secondary refining process. The findings of this research can be summarized as follows:

(1) SRS is a by-product of the stainless steel-refining process. Its main components are $\mathrm{CaO}$ and $\mathrm{Al}_{2} \mathrm{O}_{3}$, which are constructed in the compound forms of $12 \mathrm{CaO} \cdot 7 \mathrm{Al}_{2} \mathrm{O}_{3}$ and $3 \mathrm{CaO} \cdot \mathrm{Al}_{2} \mathrm{O}_{3}$, respectively.

(2) The binders with SRS as an admixture showed a strong exothermic reaction in the initial phase of hydration. This is closely related to ettringite hydrates generated by the intensive hydration of $12 \mathrm{CaO} \cdot 7 \mathrm{Al}_{2} \mathrm{O}_{3}$ and $3 \mathrm{CaO} \cdot \mathrm{Al}_{2} \mathrm{O}_{3}$ and the mixture of gypsum.

(3) The compressive strength of B30-S10-G10 at 91 days was $91 \%$ of that of slag cement (B50) and was similar to that of OPC (O100). Besides, the drying shrinkage of B30-S10-G10 was $50 \%$ and $62 \%$ of that of slag cement and OPC, respectively. The slag cement composites with the admixture of SRS and gypsum tended to a large amount of bigger and thicker ettringite hydrate.

(4) It is expected that the appropriate use of SRS, which is a by-product of the steel-making process, will solve the troublesome large shrinkage of the existing slag cement and facilitate the development of a new shrinkage reduction agent that could replace the existing expensive agents. Moreover, damage or defects caused by shrinkage cracks will also be reduced.

\section{Data Availability}

The data used to support the findings of this study are available from the corresponding author upon request.

\section{Conflicts of Interest}

The authors declare that they have no conflicts of interest.

\section{Acknowledgments}

This research is supported by the Korea Ministry of Environment (MOE) as "The advancement of scientific research and technology development in environmental science program" (no. 2017000150001). And this research was also financially supported by the Technology Advancement Research Program (TARP) (Grant no. 18CTAP-C129989-02) funded by the Ministry of Land, Infrastructure and Transport of the Korean Government.

\section{References}

[1] E. Tazawa and S. Miyazawa, "Influence of constituents and composition on autogenous shrinkage of cementitious materials," Magazine of Concrete Research, vol. 48, no. 1, pp. 15-22, 1997.

[2] S. N. Lim and T. H. Wee, "Autogenous shrinkage of ground granulated blast furnace slag concrete," ACI Materials Journal, vol. 97, no. 5, pp. 587-592, 2000.

[3] M. Polivka, Factors Influencing Expansion of Expansive Cement Concrete, ACI, London, UK, 1972.

[4] F. M. Lea, The Chemistry of Cement and Concrete, Edward Arnold Publishers, London, UK, 3rd edition, 1976.

[5] J. L. Zhao, S. L. Shen, L. B. Wang, and J. Chen, "Modification on FIP design model for interior anchorage zones of posttensioned concrete structures," KSCE Journal of Civil Engineering, vol. 15, no. 3, pp. 487-495, 2011.

[6] B. S. Cho, H. H. Lee, and Y. C. Choi, "Effects of aluminate rich slag on compressive strength, drying shrinkage and 
microstructure of blast furnace slag cement," Construction and Building Materials, vol. 140, pp. 293-300, 2017.

[7] Y. Xu and D. L. Chung, "Reducing the drying shrinkage of cement paste by admixture surface treatments," Cement and Concrete Research, vol. 30, no. 2, pp. 241-245, 2000.

[8] C. K. Nmai, R. Romita, F. Hondo, and J. Buffenbarger, "Shrinkage reducing admixtures," Concrete International, vol. 20, no. 4, pp. 31-37, 1998.

[9] Z. Jiang, Z. Sun, and P. Wang, "Autogenous relative humidity change and autogenous shrinkage of high-performance cement pastes," Cement and Concrete Research, vol. 35, no. 8, pp. 1539-1545, 2005.

[10] W. Sun, H. S. Chen, X. Luo, and H. P. Qian, "The effect of hybrid fibers and expansive agent on the shrinkage and permeability of high-performance concrete," Cement and Concrete Composites, vol. 31, no. 4, pp. 595-601, 2001.

[11] E. Özbay, M. Erdemir, and H. İ. Durmuş, "Utilization and efficiency of ground granulated blast furnace slag on concrete properties-a review," Construction and Building Materials, vol. 105, pp. 423-434, 2016.

[12] M. Collepardi, A. Borsoi, S. Collepard, J. J. O. Olagot, and R. Troli, "Effects of shrinkage reducing admixture in shrinkage compensating concrete under non-wet curing conditions," Cement and Concrete Composites, vol. 27, no. 6, pp. 704-708, 2005.

[13] X. Ping and J. J. Beaudoin, "Mechanism of sulphate expansion I. Thermodynamic principle of crystallization pressure," $\mathrm{Ce}$ ment and Concrete Research, vol. 22, no. 4, pp. 631-640, 1992.

[14] P. K. Mehta, "Mechanism of expansion associated with ettringite formation," Cement and Concrete Research, vol. 3, no. 1, pp. 1-6, 1973.

[15] V. Z. Serjun, B. Mirtic, and A. Mladenovic, "Evaluation of ladle slag as a potential material for building and civil engineering," Materials Science and Technology, vol. 47, pp. 543-550, 2013.

[16] A. Mladenovič, B. Mirtič, A. Meden, and V. Z. Serjun, "Calcium aluminate rich secondary stainless steel slag as a supplementary cementitious material," Construction and Building Materials, vol. 116, pp. 216-225, 2016.

[17] J. Montenegro, M. Celemín-Matachana, J. Cañizal, and J. Setién-Marquínez, "Ladle furnace slag in the construction of embankments: expansive behavior," Journal of Materials in Civil Engineering, vol. 25, no. 8, pp. 972-979, 2013.

[18] I. Papayianni and E. Anastasiou, "Effect of granulometry on cementitious properties of ladle furnace slag," Cement and Concrete Composites, vol. 34, no. 3, pp. 400-407, 2012.

[19] S. Monkman, Y. Shao, and C. Shi, "Carbonated ladle slag fines for carbon uptake and sand substitute," Journal of Materials in Civil Engineering, vol. 21, no. 11, pp. 657-665, 2009.

[20] I. Papayianni and E. Anastasiou, "Optimization of ladle furnace slag for use as a supplementary cementing material," in Measuring, Monitoring and Modeling Concrete Properties, M. S. Konsta-Gdoutos, Ed., pp. 411-417, Springer, Netherlands, 2006.

[21] J. Setién, D. Hernández, and J. J. González, "Characterization of ladle furnace basic slag for use as a construction material," Construction and Building Materials, vol. 23, no. 5, pp. 1788-1794, 2009.

[22] Á. Rodriguez, J. M. Manso, Á. Aragón, and J. J. González, "Strength and workability of masonry mortars manufactured with ladle furnace slag," Resources, Conservation and Recycling, vol. 53, no. 11, pp. 645-651, 2009.

[23] I. Galan, H. Beltagui, M. García-Maté, F. P. Glasser, and M. S Imbabi, "Impact of drying on pore structures in ettringite-rich cements," Cement and Concrete Research, vol. 84, pp. 85-94, 2016.

[24] J. M. Manso, A. Rodriguez, A. Aragon, and J. J. González, "The durability of masonry mortars with ladle furnace slag," Construction and Building Materials, vol. 25, no. 8, pp. 3508-3519, 2011.

[25] J. M. Manso, M. Losanez, J. A. Polanco, and J. J. Gonzalez, "Ladle furnace slag in construction," Journal of Materials in Civil Engineering, vol. 17, no. 5, pp. 513-518, 2005.

[26] J. A. Polanco, J. M. Manso, J. Setién, and J. J. González, "Strength and durability of concrete made with electric steelmaking slag," ACI Materials Journal, vol. 108, no. 2, pp. 196-203, 2011.

[27] R. Gagné, "Expansive agents," in Science and Technology of Concrete Admixtures, P.-C. Aïtcin and R. J. Flatt, Eds., pp. 441-456, Elsevier, UK, 2016.

[28] ASTM International: ASTM C349, Standard [33] Testing Method for Length Change of Mortar and Concrete, ASTM, West Conshohocken, PA, USA, 1995.

[29] J. M. Manso, D. Hernández, M. M. Losez, and J. J. González, "Design and elaboration of concrete mixtures using steelmaking slags," ACI Materials Journal, vol. 108, no. 6, pp. 673-681, 2011.

[30] D. Adolfsson, R. Robinson, E. Engström, and B. Björkman, "Influence of mineralogy on the hydraulic properties of ladle slag," Cement and Concrete Research, vol. 41, no. 8, pp. 865-871, 2011.

[31] H. Beltagui, G. Jen, M. Whittaker, and M. S. Imbabi, "The influence of variable gypsum and water content on the strength and hydration of a belite-calcium sulphoaluminate cement," Advances in Applied Ceramics, vol. 116, no. 4, pp. 199-206, 2017

[32] Y. N. Sheen, H. Y. Wang, and T. H. Sun, "A study of engineering properties of cement mortar with stainless steel oxidizing slag and reducing slag resource materials," Construction and Building Materials, vol. 40, pp. 239-245, 2013.

[33] P. Sharmila and G. Dhinakaran, "Compressive strength, porosity and sorptivity of ultra-fine slag based high strength concrete," Construction and Building Materials, vol. 120, pp. 48-53, 2016.

[34] E. Hamdy, A. A. Ahmed, M. S. Tarek, and E. Samir, "Hydration and characteristics metakaolin pozzolanic cement pastes," HBRC Journal, vol. 5, 2016, In press.

[35] D. Adolfsson, R. Robinson, J. Blagojevic, and F. Su, "Assessment of ladle slag as binder alternative for cold bonded briquettes," in REWAS 2008: Global Symposium on Recycling, B. Mishra, C. Ludwig, and S. Das, Eds., pp. 117-124, Waste Treatment, Minerals, Metals and Materials Society, USA, 2008.

[36] H. El-Didamony, S. Abd El-Aleem, and A. El-Rahman Ragab, "Hydration behavior of composite cement containing fly ash and nanosized-SiO ${ }_{2}$," American Journal of Nano Research and Applications, vol. 3, pp. 6-16, 2016.

[37] U. Neven, U. Marko, Š. Juraj, and M. Tomislav, "XRD and TGA investigation of hardened cement paste," in Proceedings of the Conference on Materials, Processes, Friction and Wear, pp. 243-249, Vela Luka, Croatia, June 2006.

[38] H. F. W. Taylor, Cement Chemistry, Thomas Telford, Westerkirk, UK, 2nd edition, 1997. 


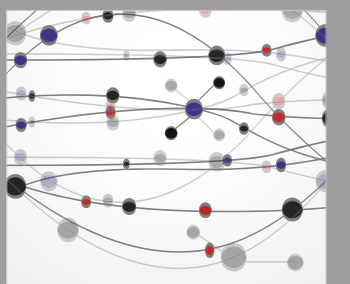

The Scientific World Journal
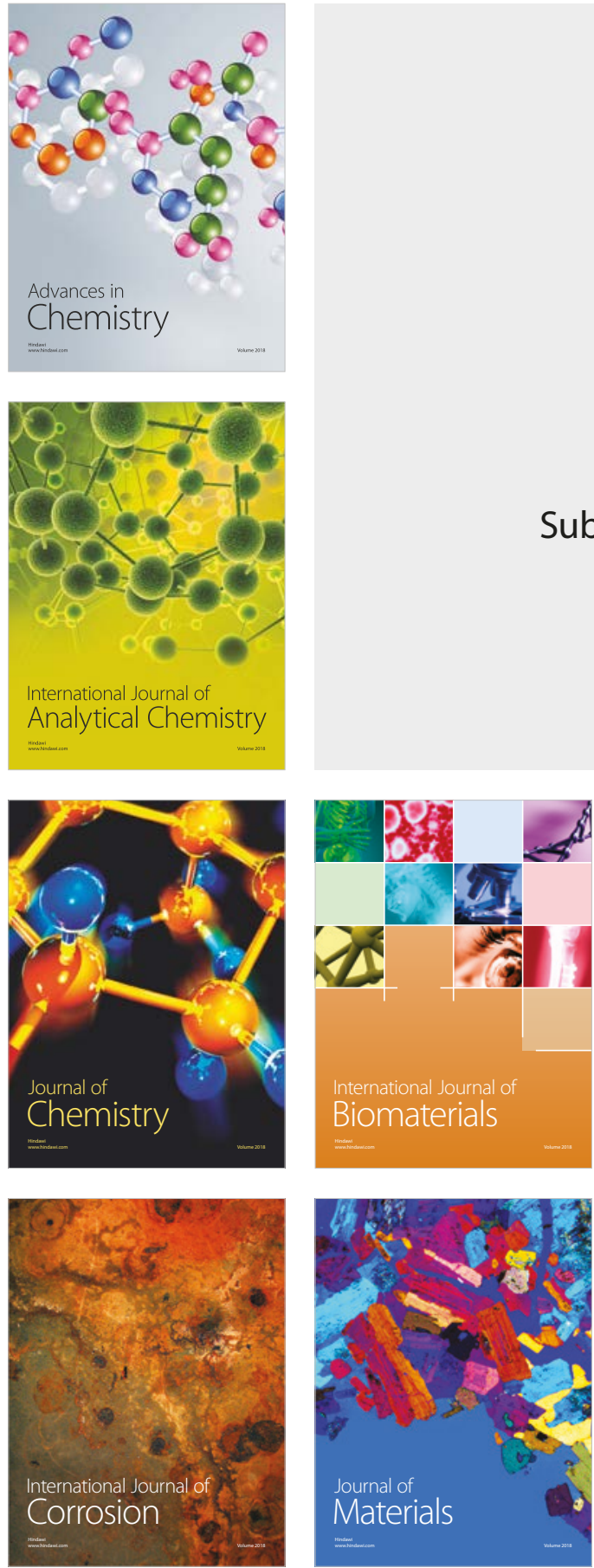

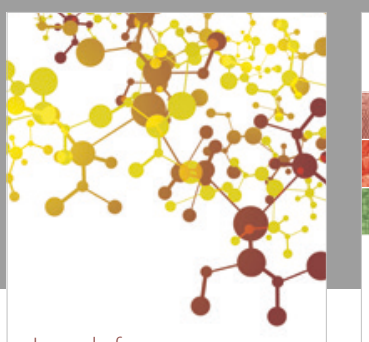

Journal of

Applied Chemistry
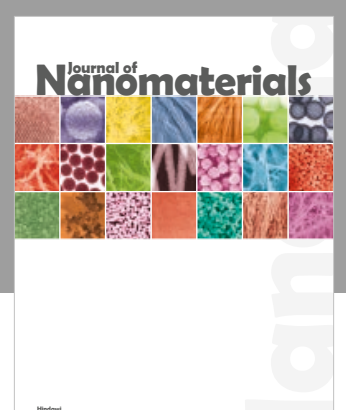

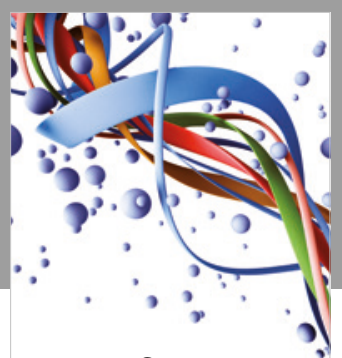

Scientifica

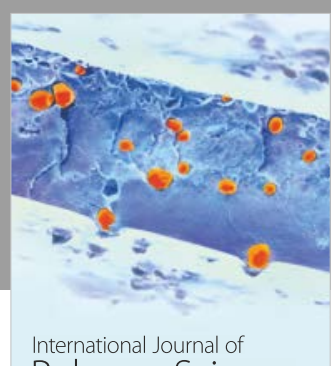

Polymer Science

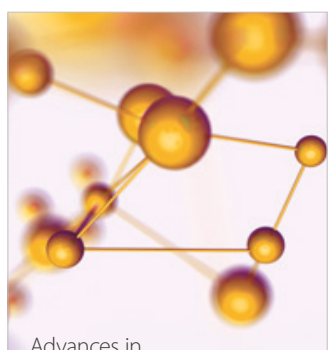

Physical Chemistry
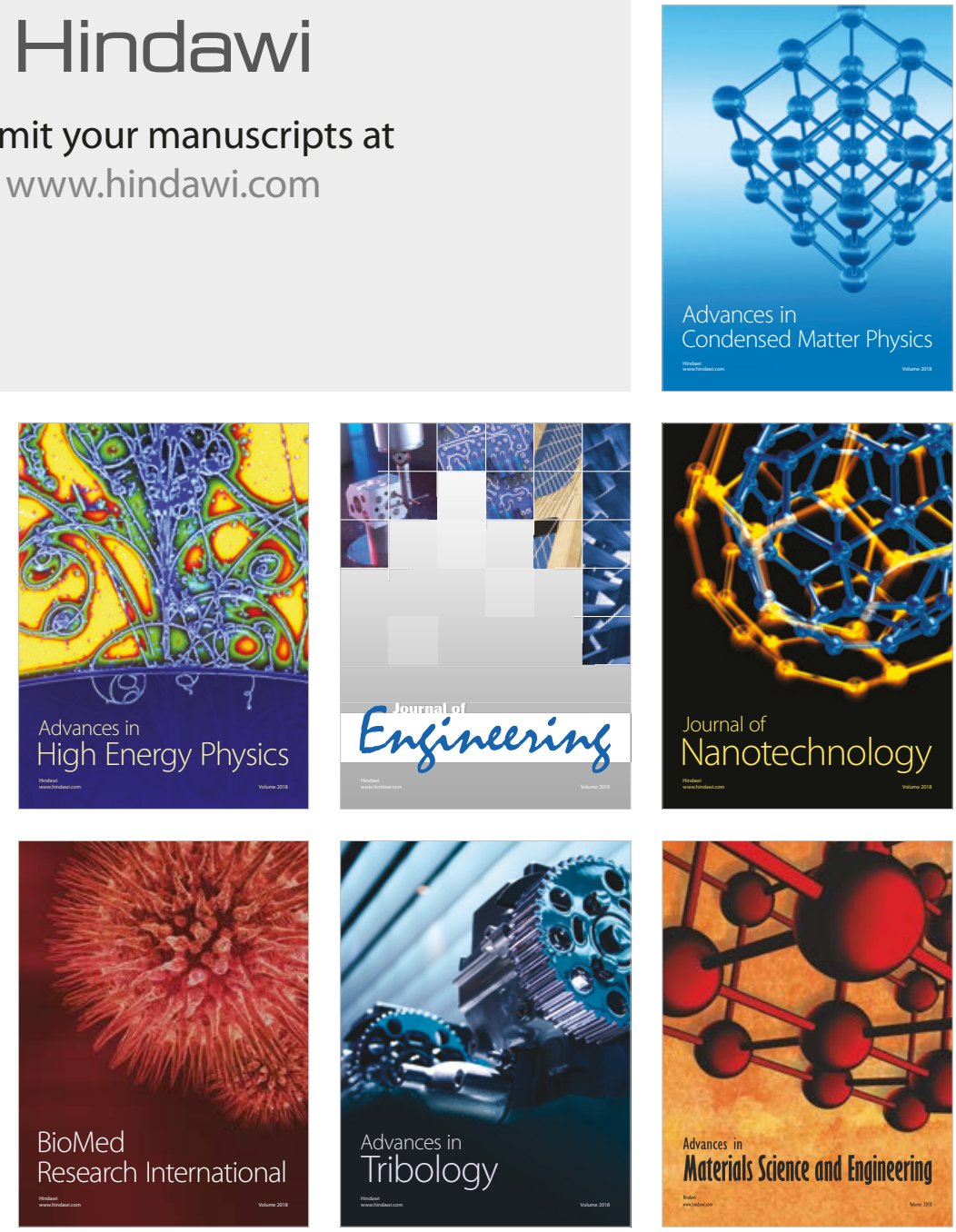